\title{
1. Financial geography and the 'social reality of finance': aspatial or 'real space' analyses of financial crises?
}

\section{Gary Dymski and Nicole Cerpa Vielma}

In 2015, the Global Network on Financial Geography (www.fingeo.net) was formally launched in Oxford. Dariusz Wójcik, the cofounder of this network, summed up the academic rationale for 'financial geography' as follows: 'The view of finance in economics became as detached from the social reality of finance, as some financial practices ... became detached from society. Social scientists in turn neglected money and finance assuming it was taken care of by economists' (Wójcik, 2017). That is, when social scientists have focused on space and its implications, they have ignored the monetary realm; and when economists have discussed that realm, they have ignored 'the social reality of finance'.

Wójcik's comment clearly takes aim at efficient-market-based financial economics: the explanatory sand-castles aimed at retaining empirical relevance at micro-market scales even while the steadily rising volume of financial crises since the 1980 s demonstrates their explanatory limits. But his observations can be extended to the complementary blind-spots he identifies. In particular, his term 'social scientists' classifies economists who do not isolate financial practices from 'social reality' as 'social scientists', not economists. No offence is intended by this geographer's telling distinction, and none is taken. This contrast reveals that just as some economists use narrow criteria for what counts as 'economics', non-economists sometimes wear blinkers about what economics is. And while many economists have broken out of this methodological cul-de-sac while remaining 'economists', very few of them have worked explicitly with 'space' in ways that most geographers would recognize.

A self-conscious field of financial geography can provide the necessary terrain for interdisciplinary exchange between economists and geographers who want to work on 'the social reality of finance'. But closing this gap will require some adjustments on both sides. Geographers, on their side, must see that the analytical conventions used in mainstream economics are well within the boundaries of the discipline. Economists, in turn, must develop much clearer ideas about the boundaries and possibilities of spatial analysis in economics. We argue here that economists hoping to establish interdisciplinary dialogues about the 'social reality of finance' must do two things: first, accept the importance of the geographic dimension; second, concede that economics is differentiated, as a social science discipline, by its analytical entry-points, not by the epistemological superiority of its insights. We illustrate our argument by exploring several economic models of financial crises in developing countries. The modelling conventions that guide mainstream models rule out both social factors and 'real space', just as they 
rule out the 'real time' approach used in Post-Keynesian economics. Bringing in 'real time' and 'real space' requires breaking with these conventions.

This chapter is divided into four sections. Section 1.1 argues that answering Wójcik's critique will require an economics that takes a 'real space' approach, parallel to the 'real time' framework that has helped to shape Post-Keynesian economics. Section 1.2 sets out some iconic models by economists of inherently spatial phenomena - the recurrent cross-border financial crises that have afflicted the global economy since the 1980s. These examples show how the mainstream toolkit invisibilizes key aspects of financial crises. Section 1.3 sketches out a 'real time/real space' approach to cross-border financial crises. This shows how this financial geography perspective can bring the 'social reality of finance' more firmly within the explanatory boundaries of economics and geography. Section 1.4 briefly sketches the main conclusions of this chapter. ${ }^{1}$

\section{1 'REAL TIME' AND 'REAL SPACE' ANALYSIS AND THE PROBLEM OF SOCIAL POWER}

What is required to build a spatial analysis incorporating the 'social reality of finance'? The first strand of Wójcik's critique, that economists treat financial phenomena as aspatial, applies both to models of high-speed trading and derivatives markets in hyper-space and to models of financial processes that incorporate no geographic dimension. A necessary condition is recognizing processes or events that unfold in different spaces. This immediately implies that the agents involved are heterogeneous. This can be established very simply by assuming that everything doesn't happen in the same place, and it is costly to move from one location to another. For example, Townsend (1983) uses this assumption to explain the use of money.

More is needed, though, to incorporate the 'social reality of finance'. The situation of spatially separated agents maximizing utility through exchange is reversible: it has no social dimension. A sufficient condition for bringing in 'social reality' is to specify that agents separated in space have location-specific differences in their choice sets or resources. So location is not reversible, and conveys either more options or fewer. This division can take many forms - two sides of the tracks, global North and global South, and so on. It immediately conveys differences in social power, which is inherent in differential constraints or choices. Analyses can be termed 'real space' when they incorporate non-reversible space with one or more social dimensions.

An analogy to this idea of 'real space' is available in the 'real time' perspective that underpins one of the several strands of Post-Keynesian economics (Hamouda and Harcourt, 1988). Shackle (1974) and Davidson (1978) led the way in demonstrating how the concept of liquidity preference introduced by Keynes implied the centrality of 'real time' in economic dynamics. Economic agents confront 'real time' when they have to make decisions in the face of irreducible uncertainty - and not simply probabilistic risk - about the outcomes that may result. This leads to a major emphasis in Post-Keynesian economics on the need to stabilize the macroeconomic environment and aggregate spending streams, as this minimizes disturbances in beliefs and disruptions in the confidence required to make irreversible investment and consumption decisions.

'Real time' analysis differentiates Post-Keynesian approaches to financial and macroeconomic analysis from mainstream models, which do not allow for fundamental uncertainty. 
'Real space' is an independent dimension, which in turn is missing from most mainstream and Post-Keynesian writing (Dymski and Kaltenbrunner, 2021). When time is 'real', the unforecastable unknown itself affects human decisions in the present; when space is 'real', what can and cannot be done depends on factors beyond physical distance itself.

Some Post-Keynesian work does incorporate 'real space' analysis. A prime example is the work of Dow (1987) on the differences between the functioning of banking systems in a national economy's core and peripheral regions. She argues that the periphery is subject to credit starvation in periods of financial distress - as a consequence, levels of financing, liquidity, and growth differ in time and across time. This finding rests implicitly on the differential social power of core and periphery, which can be traced to differences in spatial resource endowments and in market access.

Note that 'real space' analysis thus requires references to physical realms that are divided in some manner by borders. Processes or the movement of entities then differ according to whether they are contained inside a border, exist outside of it, or cross it. Note as well that borders exist at different spatial scales - regions, nations, cities, neighbourhoods, even streets. Most economic analysis that works with given spatial layers - nation-states, or city-regions, etc. - uses these as foundational analytical units; for example, one might read that 'Mexico took on foreign lending'. Geographers, by contrast, see spatial layers as sites of social processes. Lefebvre (1991), in his foundational analysis, discusses the 'production of space' (or 'social space') (ibid., p. 67) through 'spatial practices' (ibid., pp. 16-18). Any given spatial layer contains actors and objects connected through 'upward' and 'downward' linkages to larger and smaller spatial areas via purchases and sales, rights and obligations, permissions and denials. Soja referred to the 'spatiality of human life' as 'thirdspace', accompanying the 'historicality and sociality' (Soja, 1996, p. 3) of lived experience.

\section{Economists' and Geographers' Approaches to Power}

This brings us to the problematic of power. One challenge in overcoming the gap identified by Wójcik is that economists view power through the lens of market transactions, and geographers through the lens of social relations more broadly. For economists, power involves mechanisms that either redistribute gains and losses outside of market transactions, or situations in which one party to a market transaction has inferior alternatives and thus cannot bargain freely over terms and conditions of the contract achieved. As Bowles (2006, p. 256) puts it, power accrues to the party on the 'short' side of the market. Power is little discussed, in any case, especially by mainstream economists, who use Walrasian general equilibrium as their analytical reference point, and prefer explanations that meet the Occam's Razor criterion - deviating as little as possible from the ideal of agent choice based on utility maximization (Dymski, 2014).

Some geographic work follows this market-centred approach. Cohen's The geography of money (1998), referenced below, defines the root of financial power as national governments' 'monopoly control over the issue and management of their own money' (Cohen, 1998, p. 4). But since 'currencies increasingly are employed outside their country of origin, penetrating other monetary spaces ... power has been redistributed not only between states but, even more important, from states to market forces. ... authority must be shared with other market agents, in particular the users on the demand side of the market' (ibid., p. 5). 
So the approach of Cohen - an international political economist - stays within the 'market power' conception. Many geographers take a broader approach. For example, Lefebvre (1991) argues that capital exerts power over the production of space, and indeed is hegemonic over space. Soja also uses this terminology: 'Hegemonic power ... actively produces and reproduces difference as a key strategy to create and maintain modes of social and spatial division that are advantageous to its continued empowerment and authority' (Soja, 1996, p. 87). Richard Peet's The geography of power covers similar ground to that of Cohen, but follows the approach of his fellow geographers:

With the term 'geography of power' I refer to the concentration of power in a few spaces that control a world of distant others. My argument is that a new kind of economic power system has arrived on the world scene. Power has increasingly been accumulated at the global level by governance institutions - the G7/G8, the European Union, the Bretton Woods Institutions and the United Nations. (Peet, 2013, p. 1)

Peet's subsequent discussion focuses on global finance capital, 'the influence of capital markets on the making of global development policy by government and governance institution' (ibid., p. 35), and the revolving door between Wall Street and government, inter alia. But these are the insights of a geographer writing geography. Can such open discussions of power as one aspect of the 'social reality of finance' be encompassed within economics?

\subsection{MAINSTREAM ECONOMIC MODELS OF FINANCIAL CRISES AND GLOBAL IMBALANCES}

Since the 1980s, mainstream macroeconomic models have been held to the same explanatory standard that previously pertained only to microeconomic models: the economist building a model must demonstrate how the observed result follows from the rational choices of one or more individual agents in a representative market setting. This reflected a shift away from the macroeconomic models that had prevailed since World War II, which had featured the structural characteristics of sectors of the economy and largely ignored rational choice questions, which were considered microeconomic issues. The downfall of the older generation of models coincided with the chaotic macroeconomic and geo-economic events of the 1970s. The moment was ripe for the long-brewing methodological critique of Keynesian macroeconomics by Robert Lucas and his New Classical associates. This new orthodoxy insisted on models of rational behaviour under rational expectations. This section sets out two illustrative models that conform with these mainstream conventions.

In the early 1980s, recession and skyrocketing interest rates took hold across the world, and led first Mexico and then other Latin American nations to default on their cross-border loans. ${ }^{2}$ While economists such as Diaz-Alejandro (1984) pointed to structural dimensions of the global economy and of Latin America, building a mainstream model required answering a different question: how to explain the Latin American debt crisis while conforming with the 'rational agent' requirement imposed by the macroeconomic reformation? One defensible approach was to model the lender-borrower relation as involving a principal-agent problem because of asymmetric information: lenders don't know how borrowers will perform once they receive loans, and thus face potential loss from this 'moral hazard'. This became the dominant explanation of the Latin American debt crisis (Eaton et al., 1986). The borrower country, 
conceptualized as a unitary agent, compares the gains from repaying and from defaulting, and rationally defaults when the penalty for defaulting is set too low.

While this model purports to explain loan defaults across space, it is aspatial - space plays no role. This model is also asocial. It ignores the diverse agents interacting at multiple spatial scales prior to default - the companies unable to pay, the governments stepping in, the workers shouldering the higher public debt burden. Instead, the borrower is conceived as a unitary agent, a 'country'. While it clashed with the actual chronology and specifics of the case, this model proved durable. Krugman (1998) used it to argue that the root cause of the East Asian crisis of 1997 was a rampant moral hazard in Asia's state-controlled banking systems. This same model has been deployed in explanations of the Eurozone and subprime crises (Dymski, 2014).

Our second example is the 'shortage of safe assets' explanation of the Great Financial Crisis. In Fall 2008, Caballero et al. (2008, p. 1) explained: 'The current financial crisis has its origins in global asset scarcity, which led to large capital flows toward the United States and to the creation of asset bubbles that eventually burst.' Caballero and Krishnamurthy (2009, p. 1) elaborated further:

A key structural factor behind this [2008] crisis is the large demand for riskless assets from the rest of the world. In this paper we present a model to show how such demand not only triggered a sharp rise in U.S. asset prices, but also exposed the U.S. financial sector to a downturn by concentrating risk onto its balance sheet. ... capital flows into the U.S. are mostly non-speculative and in search of safety. ... In other words, as global imbalances rise, the U.S. increasingly specializes in holding its 'toxic waste'.

This model is aspatial and asocial, as was the moral-hazard model of debt crises; replacing that model's borrower/lender binary is a safe-asset country/risky-asset country binary, in a stripped-down setting: the model has neither a banking nor a financial sector. In this case, the globally peripheral countries have not exploited a poorly solved principal-agent problem, but compensated for their own nations' inability to create safe assets by overbidding for US safe assets, leading through portfolio effects to excessive risk migrating to US financial markets and generating a bubble there.

As Dominguez (2008, p. 56) put it: 'This ambitious paper ... seeks to explain, in one model, all that is wrong in the global economy. The culprit is underdeveloped financial markets in emerging Asia and the oil producing countries. U.S. fiscal and monetary policies play no role.' Its description of the facts of the case is wrong, as was the moral-hazard debt-crisis model. Federal Reserve economists Bertaut et al. (2011) have shown that it was European investors, not developing economies, that accounted for the vast majority of cross-border asset-backed securities purchases in advance of the 2008 crisis. Nonetheless, Caballero and his co-authors have doubled down, arguing that 'the supply of safe assets has not kept up with global demand. The reason is straightforward: the collective growth rate of the advanced economies that produce safe assets has been lower than the world's growth rate' (Caballero et al., 2017).

\section{Aspatiality and Atemporality in Mainstream Models of Global Processes}

More examples of mainstream models of cross-border crises or processes could readily be found; but these two are sufficient to demonstrate the pattern. The moral-hazard and safe-asset 
explanations rest on thinly specified models with incomplete representations of even the processes they are explaining.

The moral-hazard model of the Latin American crisis denotes the borrower as the sovereign - a misrepresentation. The 'borrower' in this model, the sovereign nation, was not originally part of the credit-market transaction with the overseas lender. Financial structures within the borrower countries are ignored, as is the commodity-price decline. Krugman's model of the East Asian crisis blames crony-capitalism - the provision of credit to borrowers in affected East Asia countries on the basis of clientelism - ignoring the social and institutional basis of these very nations' high growth rates. Quite simply, establishing a moral-hazard dilemma on the basis of a binary principal-agent relationship is the simplest - Occam's Razor - path to an argument rooted in agent incentives and optimization; the historical and institutional context is a distraction. The safe-asset argument, in turn, ignores other processes that could explain the systematic inflow of capital into the US, such as deindustrialization and financial deregulation in the 1980s.

'Real space' - the fact that all events unfold in interconnected spatial sites or across spatial borders - and 'real time' - the context-dependent impact of the uncertain future on liquidity preference - are completely absent. While these models pertain to agents and instruments separated in space, space plays no role. And because of the aspatiality of the constructs, which places all parties within the model on an imaginary even playing field, power differentials are invisibilized. Another dimension of aspatiality is that the multi-scalar social and political context of the nation-states in question receives no attention. Economic dynamics at the regional and global scales larger than the borrower and safe-asset seeking nations are ignored, as are economic and social dynamics within these nations. The fact that cross-border constraints have to be met - and indeed, are part and parcel of the flows highlighted in the 'search for safe assets' story - is ignored, as are the implications of those cross-border constraints for the net direction of flows. Regarding 'real time', all payoffs are well-defined in the moral-hazard model. In the 'shortage of safe assets' model, the nature of 'safe' versus 'risky' assets is not discussed at all; the problem of running for safety itself, which motivates the model, is described as a matter of optimal portfolio allocation. Uncertainty and asymmetric power are hiding in plain sight, but never discussed.

\subsection{FINANCIAL POWER IN GLOBAL SPACE}

The reason to make space for financial geography in foundational discussions of the political economy of financial processes, outcomes, and systems is that there are different stories to be told than can be reached while working within the confines of models disciplined by concerns about Occam's Razor distancing from general equilibrium.

In this section, we will sketch out the bare bones of a 'real time', 'real space' analysis encompassing the two global scenarios covered in Section 1.2 - the occurrence and consequences of sovereign debt crises, and the driving forces of global imbalances. Instead of highlighting developing-economy wealth owners' search for safe assets, we focus attention on structural factors that have led developing-economy sovereign nations to endure financially fragile - risky - structural positions. And instead of considering why those sovereigns are such reluctant payers, we consider structural pressures compromising their ability to pay. 
This change of perspective requires that we include within our analytical focus not just the nation-state level, highlighted in the models covered in Section 1.2, to the global architecture of power in finance. This short section shows how an alternative to the economic models summarized in Section 1.2 can be replaced via a financial geography that encompasses real time and real space. 'Real time' here connotes more than the situation of the decision-maker facing uncertainty. The decisions made across the face of the nation and, indeed, the world, lead to flows of goods and services and to the accumulation or decumulation of wealth in each period of time. The location of every decision-maker in the world, and the resources at her command, affects their options and their power. And power resides in some locations, not in others. So a 'real time', 'real space' approach, to be fully expressed, has to be historically informed and institutionally grounded, and conscious of the distribution of power.

In the suggestive sketch set out in this section, we first delineate the origin and shape of financial power at the global scale, deployed to establish rules of the game; then we turn to nation-states inside or seeking to enter the global core; and finally we consider the situation of nation-states in the periphery. These are, to summarize crudely, zones of control, of dominance, and of submission. Our focus in every one of these spheres is to consider in what power consists.

\section{Power in Finance at the Global Spatial Scale}

At the core of the core of global finance, even years after the end of the Bretton Woods system, are the United States and its too-big-to-fail megabanks. This position was achieved via a series of radical policy measures that remade a regulated system that was losing customers to the money and bond markets by the end of the 1970s. Ending geographic segmentation and deregulating banking instruments and product-lines, together with an extended bank merger wave (Dymski, 1999), fed new capital into the financial system and bolstered the importance of the country's money-centre banks. These large banks' attempts to replace lost customers by opening new markets, including Latin America and East Asia, led first to a financial crisis (as noted above), but then to the emergence of too-big-to-fail megabanks in the US from the mid-1980s onwards.

Then and subsequently, the US Federal Reserve demonstrated the capacity and willingness to support its national-champion banks; and it showed its resolve as a lender-of-last-resort in a series of financial panics from the 1980s onwards: backstopping the money-centre banks that had overlent to Latin America and to the 'oil patch' region of the US; the 1987 stock-market crash; the Mexican Tesobono crisis of 1994-1995; the 1997 East Asian financial crisis; the 1998 Long-Term Capital Management collapse and the 1998 Russian financial crisis; the bursting of the IT bubble in 2000 . Had there been any doubts about whether the US Federal Reserve could, by issuing its own currency as needed, satisfy 'flight to safety' impulses in a crisis-prone world, these were laid to rest.

From 1980 onwards, the current-account deficit grew, and the capital-account surplus along with it. The growing willingness of global markets to hold dollars, encouraged by the Federal Reserve's steady hand, facilitated the steady inflow of capital; this provided financing for the growing federal-government deficit, and consolidated the permanence of the systematic US current-account deficit. The US used the 'exorbitant privilege' (Eichengreen, 2010) afforded it by the global dominance of the dollar to sustain and fund large budget and current-account 
deficits. The Treasury liabilities emitted to support these imbalances are held by central banks the world over.

With this stable neoliberal structure came positional power - the ability to define rules of the game. ${ }^{3}$ Once the US had done so, other countries hastened to deregulate their financial systems. US housing finance was reshaped from a bank-based to a market-based credit system. The securitization process at the heart of this system began with safe, 'plain vanilla' mortgage loans, but by the 1990s expanded to riskier loans, including subprime mortgages. An interconnected network of shadow banks centred around megabanks and investment banks (Wójcik, 2012) grew to originate, service, and hold these loans. Again, overseas capital flowed in to secure its share. Much of this new system either has since the 1980s escaped or challenged regulatory oversight.

This was the system being put in place when the Latin American crisis unfolded, and that was solidifying its gains when empirical evidence of a hunt for 'safe assets' could first be detected. The global economic consequences of this system are made devastatingly clear in D'Arista's recent volume All fall down (2018). D'Arista shows that financial globalization creates a global pyramid, under the terms of which only the country at the top can stop panics when financial crises occur. She demonstrates, as suggested here, that problems of unchecked financial flows are reinforced by structural imbalances in current and capital accounts. Further, she shows that the persistent neoliberal-era US current-account deficit implies that developing-economies' holdings of US liabilities are supporting financialization globally, and increasing pressures that destabilize governments and increase the returns to global financial predation.

The 'real time', 'real space' dimensions are central to this evolving replacement system of finance. Location in space (and time) matters, in terms of what vector of forces are at work, and with what effect, across the face of the inhabited planet. And indeed, we might differentiate between different spaces and, in turn, agents' positions within those spaces. If one is not located at the centre of the system, it matters greatly for financial dynamics and differential power both whether one is located in the core or periphery, and in turn where one is positioned, whether in the core or periphery.

\section{Nation-States in the Global Financial Core}

Beyond the hegemonic dollar, which nations are in the global financial core? Cohen observes that governments that maintain 'monetary monopoly' over payments systems accrue four powers: 'political symbolism, seigniorage, macroeconomic management, and insulation from external influence' (Cohen, 1998, p. 119). Cohen's monetary monopoly, however, establishes only territorial integrity, not the viability of national finance beyond its own boundaries.

There are three possible projections of financial power outside a nation's own boundaries. The first is the ability to emit a currency that other nation-states willingly hold. The test of this lies in global currency reserve holdings. The International Monetary Fund (IMF) lists the holdings of only eight nations' currencies in its published registry: this is a small club. Dollar holdings far exceed those of the euro, which in turn vastly outstrip those of the UK pound and Japanese yen, with Chinese renminbi holdings even farther behind. Beyond the even smaller global reserve holdings of Canadian and Australian dollars and of Swiss francs, this club has no other members. 
The second power arises when a given nation's currency is used in contracts outside its own borders. An example arises when one nation's currency is used to finance investment outside its national borders. When this is done recurrently, this nation's legal practices and business service firms can shape the cross-border financial processes in which they participate. Kaltenbrunner and Lysandrou (2017) show that virtually no nations' currencies now challenge the dominance of the US dollar in this regard. A third power is the capacity to provide third-party financial services to foreign buyers. The best example here is the City of London, whose foreign-currency and offshore bond markets are world leaders, almost a century after the British pound lost its central place in the global monetary system.

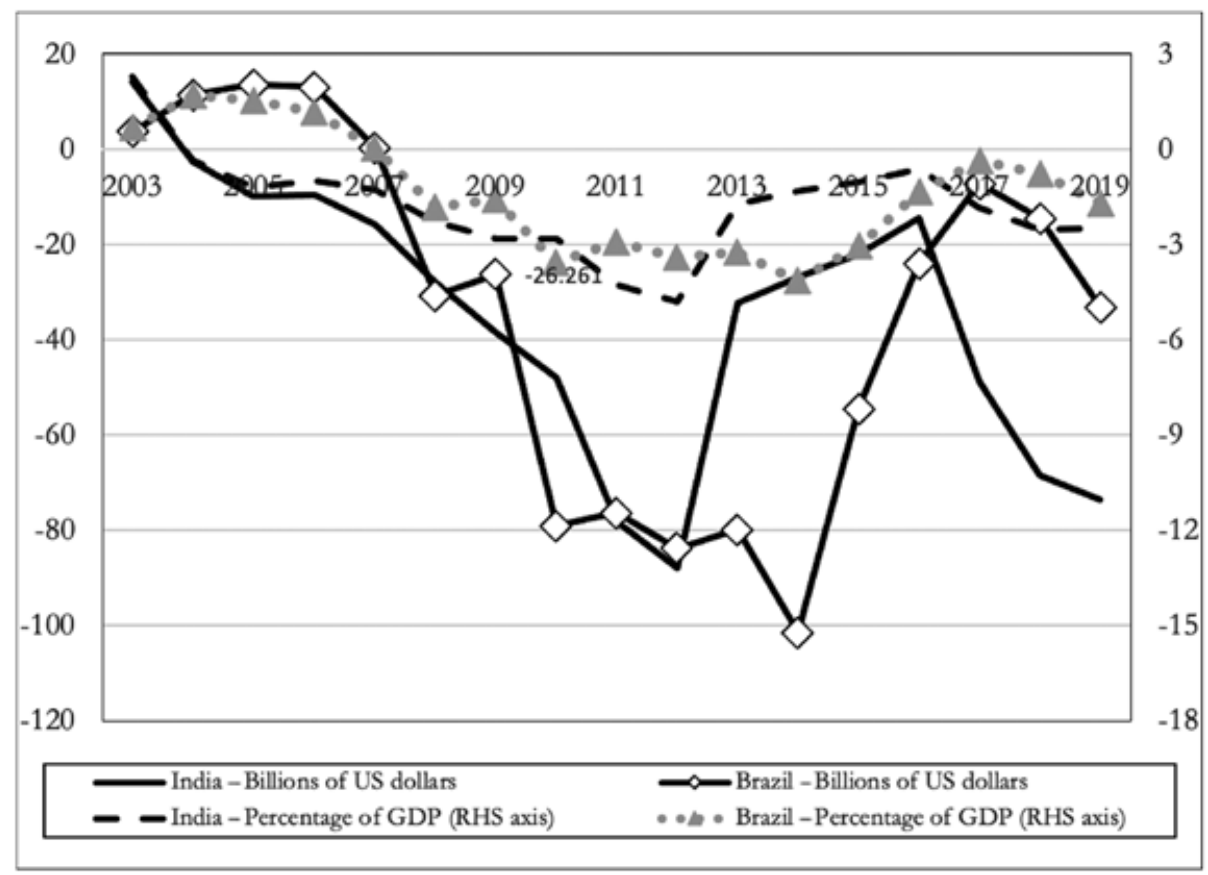

Source: International Monetary Fund.

Figure 1.1 Two measures of current-account balance, India and Brazil (2003-2019)

Projections of any of these three cross-border powers is sufficient to qualify a nation for the global financial core. Membership in the core entails two benefits. First is guaranteed safety: nations in the core maintain very low reserves; they do not fear systematic speculative attack - speculators know their central banks can emit domestic money (reserves) at will, without reserve. The US, Germany, France, and the United Kingdom - home nations of aggressive, globally active megabanks that have attracted the close scrutiny of the Financial Stability Board - have reserve totals substantially lower than those of non-core nations with smaller income levels. The second benefit to core nations is that, precisely because they are immune to speculative attack, they can host financial firms that can take stakes in other nations' systems 
and/or engage in zero-sum speculation with external parties. This can be considered offensive power; it has enabled these core nations' largest banks to expand aggressively, to sizes sometimes surpassing the GDP levels of their home nations.

\section{Nation-States in the Global Financial Periphery}

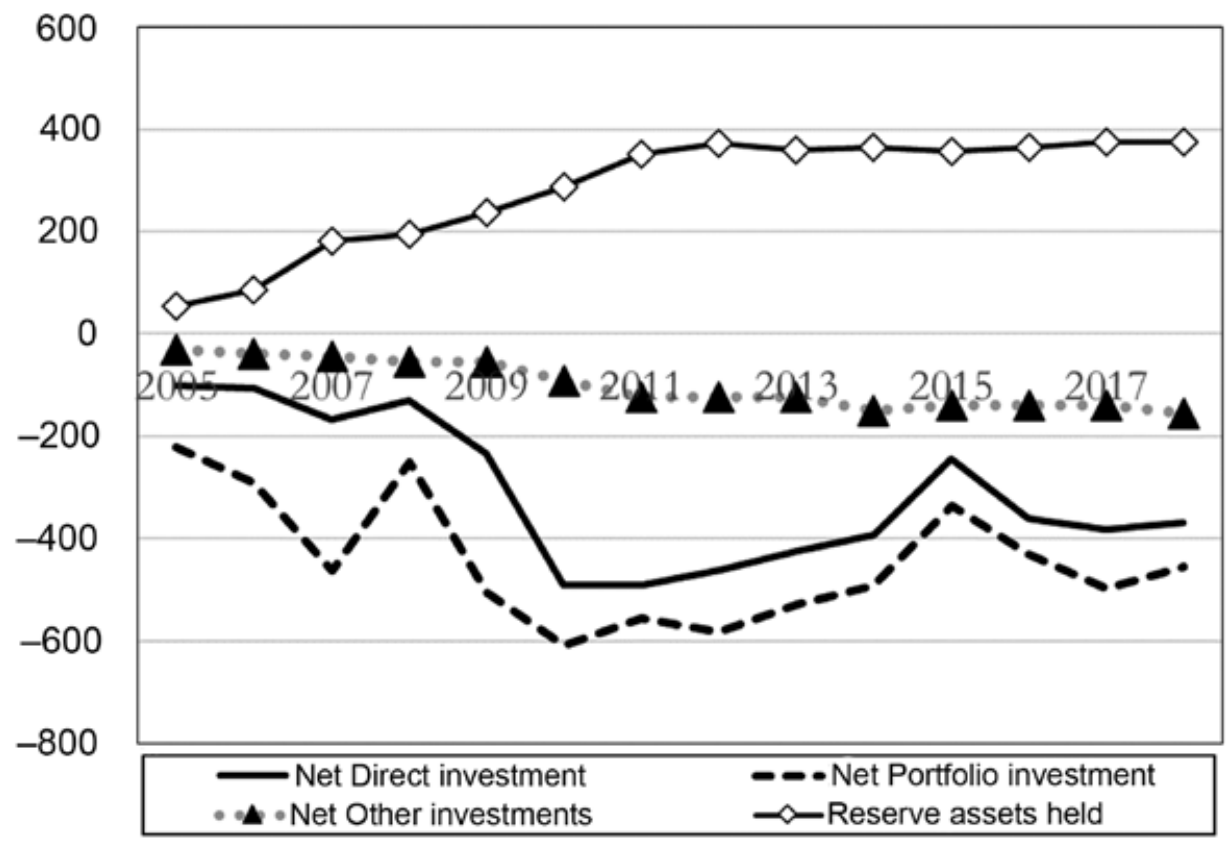

Source: International Monetary Fund.

Figure 1.2 Net international investment position, India (2005-2018) (billions of US\$)

A nation is classified in the global financial periphery when it does not maintain 'monetary monopoly' over its own territory and/or when it lacks any of the three cross-border powers detailed above. To fail both the former and latter tests, of course, puts a nation in the deep core of the periphery. A nation that lacks any cross-border power but retains monetary monopoly is vulnerable to attack by financial firms based in nations in the financial core. Further, such a nation is more vulnerable to 'sudden stop' crises (Dymski, 2019), especially if it depends on a flow of financing from external lenders.

An examination of the cross-border accounts of many developing economies, including India and Brazil, reveals that despite having current-account deficits, these countries are over-borrowing so as to build up their stocks of currency reserves. Protection from attack - the power to be left alone - is a key motive for many developing nations. To see this graphically, first consider Figure 1.1, which shows that both countries' current-account balances shifted from positive to negative in the global financial crisis period, recovering somewhat thereafter. The inescapable logic of cross-border balances is that a nation's current account deficits 


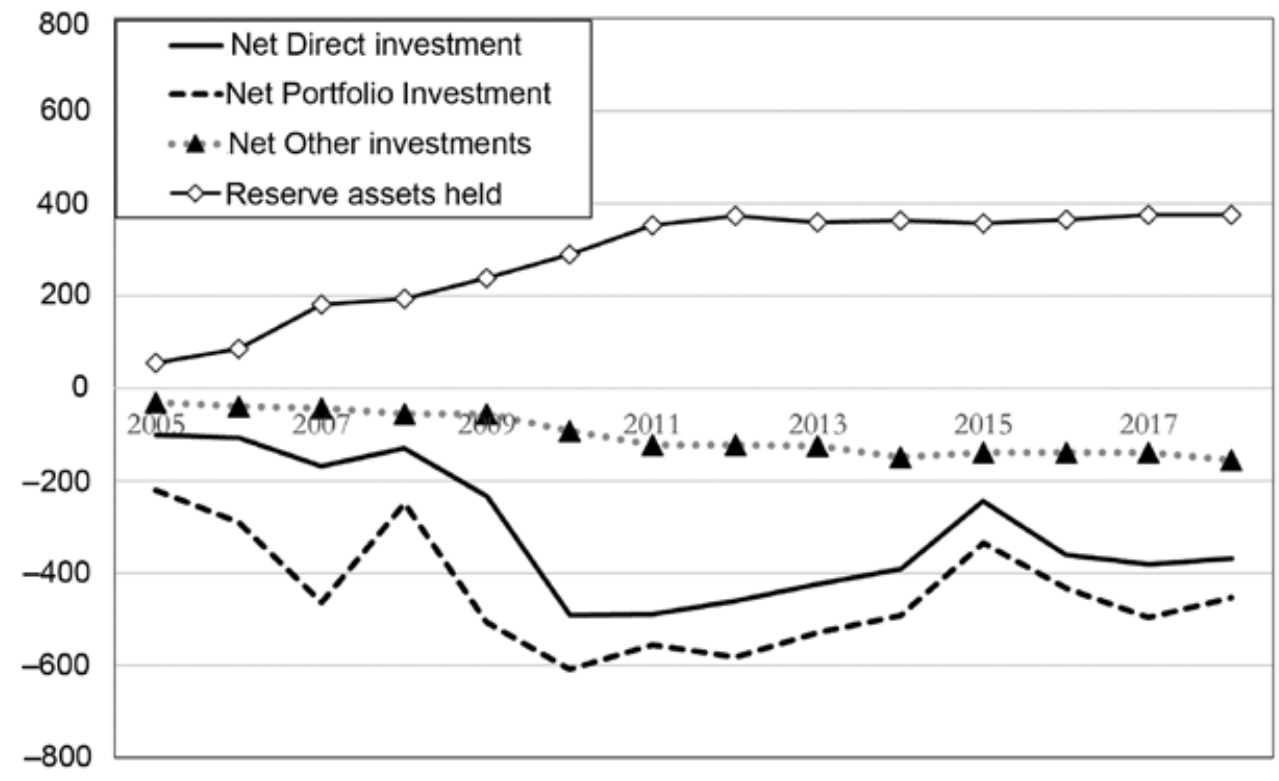

Figure 1.3 Net international investment position, Brazil (2005-2018) (billions of US\$)

(resulting in net outflows of domestic currency chasing foreign goods and services) must be financed either by an inflow of foreigners' savings (such as foreign direct investment) or by spending down its stock of foreign reserves. The implication of Figure 1.1 is thus that foreign savings should be increasing or reserves declining, or both.

Figures 1.2 and 1.3 provide the evidence for the capital-flow side of this equation by summarizing the net investment position of these two countries in the same time-frame. Net investment position is positive when a nation's wealth-owners net purchases of foreign assets exceeds foreigners' purchases of domestic assets (and vice versa). So net investment position should be negative for both India (Figure 1.2) and Brazil (Figure 1.3). It is, in both cases, for three categories of net investment (portfolio, direct, and other). The anomaly is that in both countries, reserve assets held rise systematically throughout the 2005-2018 period depicted. As noted, reserves should remain constant or be reduced when the current account balance is negative. But both countries have, to the contrary, amassed systematically more holdings of foreign currencies. They have, in effect, over-borrowed so as to protect themselves from speculation.

Financial fragilities arise for nations lacking financial power. The asymmetric power of core nations vis-à-vis peripheral nations - immunity from speculative attack - constitutes a severe danger for the latter. Countries whose currencies have begun to enter open global markets are under most threat. To offset that disadvantage, a peripheral country may take action by enhancing its defensive power. Defensive power can take several forms. One is to impose inward capital controls. This move may be ruled out by prior action put in place after IMF 
intervention in the wake of a previous financial crisis. A second form of defensive power is the build-up of excess stocks of foreign-currency reserves. ${ }^{4}$

\subsection{CONCLUSIONS}

This chapter has argued for the importance of establishing a financial geography that can offer counter-analyses to mainstream economists' aspatial models of spatial processes. Comparing economists' models of imbalances and crises with spatial analyses focused on asymmetrically distributed economic power illustrates why financial geography is needed. Economists' models are disciplined by their fealty to rational behaviour and to their own version of Occam's Razor. These pre-commitments make it difficult or impossible to introduce important institutional and historical elements into their models; as we have seen, this often leads to models that are descriptively wrong or partial, and that ignore history rather than heeding its lessons.

We have made three interlocking arguments about how financial geography can provide the discursive space for meeting these goals. First, non-economists (especially geographers) must expand their own criteria for what counts as economics, to include the richer palate of methodologies and perspectives that draws many economics to the practice of heterodox - not mainstream - economics. Second, economists - especially heterodox economists - must more explicitly recognize the importance of 'real space' - the spatial dimension - in their analyses. It is often, as noted, hiding in plain sight in discussions of power, inequality, stratification, and so on. Third, economists, geographers, sociologists, and other social scientists must be willing and able to either work with terms that are accessible to those outside their own specialty fields, or to work as translators. In sum, constructing a financial geography that is fit for the purposes designated here is, at heart, a bridge-building exercise.

Some final reflections on Wójcik's inadvertent dismissal of the heterodoxy in his use of the term 'economist' are pertinent in suggesting the way forward. The question is, in asking geographers to redefine 'economics' more widely, so as to encompass that discipline's heterodoxy instead of just its mainstream 'core', are we suggesting that 'anything goes'? In effect, are we asking geographers focusing on financial geography to have a conversation with a category of economics that is an empty set? The answer is, 'no, but it's complicated'.

The fact that what binds 'heterodox' economists together is their opposition to mainstream orthodoxy is a well-worn observation, usually expressed as a joke. But after acknowledging this joke, it is important to dig into its deeper meaning, which has changed over time. Post-Keynesian economists engaged in a lengthy debate three decades ago, discussed in Hamouda and Harcourt (1988), about whether those identified as Post-Keynesian economists shared a particular set of core methodological and conceptual commitments. The one concept agreed on by all was that aggregate demand feeds back on and co-determines output levels. Even Keynesian uncertainty was not an essential concept for some varieties of Post-Keynesianism: indeed, the importance of the hyphen between 'Post' and 'Keynesian' even became the object of debate. The recent effort by Marc Lavoie (2015) to compile the key findings and methods of Post-Keynesian economics begins with a long discussion of the different 'schools' of Post-Keynesian thought.

But the core of the old joke - the rejection of the notion that economic theory should be based, to the extent possible, on the optimizing behaviour of individual or representative agents coordinating their activity through market exchange - actually is the definitive unifying 
thread. To deny this is to pose, for oneself, the question of how to organize a coherent set of ideas about how the provisioning system fits into and interacts with the broader social world outside of it. Throughout this chapter, the term 'economy' and not 'political economy' has been used to designate this system. The term 'political economy' has its uses, in acknowledging that economic relations cannot be defined independent of the political context in which they exist, whether 'democracy', 'socialism', 'fascism', or other alternatives. But the arrangements for provisioning also have a social context, and an ecological one.

Parallel debates to those that have preoccupied Post-Keynesian economists about their common identity have gone on, and will continue, for Marxian economists, for institutional economists, and for others. Arguably the core commitment of feminist economics - that every agent is gendered, and this matters in economic behaviour, organization, and outcomes - necessitates a positionality outside the core of the mainstream. The same logic applies to ecological economics. This brings up a key point about 'heterodox economics' itself. This term has emerged in the past quarter-century (Lee, 2009; Carpintero, 2013) precisely because of the flowering of work outside the mainstream. Beyond the old joke, Dymski (2014) has pointed out that this resurgence is linked to various social and political movements - for women's rights, for racial equality, for ecological sustainability, for reduced inequality, and so on. There can be no expectation of uniformity in economic heterodoxy, because its membership is multiple, and the research it stimulates makes points that are pertinent from different points of criticality about existing society.

The critical move designated herein for economists is to embrace 'real time'; this is shorthand for identifying with core elements of Post-Keynesian economics, on one hand; but accepting 'real time' and the associated insight that aggregate demand 'matters' does not require self-designation as a Keynesian or Post-Keynesian. Parallel to 'real time' here has been the centrality of 'real space'. There are certainly domains of geographic theory where space is defined in an abstract way, shorn of any links to social relations; the literature on size-ordering of cities comes immediately to mind, as does the literature on geospatial mapping. That said, the frameworks used by those who practise what might be termed 'abstract geography', for our purposes here, in no way play the role in geography that the core mainstream model does in economics. It would arguably be impossible to locate a conceptual point of reference in geography that is equivalent to the general economic equilibrium in economics. This has liberated geography, as a discipline, from stark designations about whose work is 'serious' and whose is not.

There is, however, something about contending a power centre within the economics discipline that defends the priority of the market over and against 'society' that has been productive for heterodox economists. It generates bonds of solidarity. The struggles to build heterodox insights in economics, as tortured and multiple as they have been, do bring practitioners together. The journey is never individual; for one has to identify and join in with other heterodoxy working on similar problems or methods to oneself. This opens up a ready space for collaborative discussion between heterodox economists and economic geographers, in particular, as the latter often feel their work is undervalued and overlooked in policy discourse.

But this sense of being excluded from a mainstream narrative that, despite the good intentions of those who accept its methodological premises, can bind geographers and heterodox economists in what should be the defining purpose of financial geography. In the absence of an effective counter-narrative, the consequences of global financial power go unremarked, even 
unseen. Financial geography can fill this gap. Spatialized representations of power can capture some of the key financial dynamics of our time. Space is not unitary and does not follow one repeating pattern. Societies in 'real space' encompass tableaus of exploitation at many different spatial - and temporal - scales. These points are, in many cases, well known already to geographers; but they are absent in the narratives and models of economics that drive discussions of policy alternatives. Efforts to redress the imbalance of global spatial power must begin with efforts to rebalance the governing analyses of its drivers and consequences.

\section{NOTES}

1. This chapter builds on insights developed in Dymski and Kaltenbrunner (2021) and in Dymski (2021). Some of Section 1.3, and some sentences in Section 1.4, are drawn from the latter paper.

2. Dymski (2019) provides a comprehensive review of international financial crises since 1980.

3. A nation can be considered fully hegemonic in financial terms when its currency establishes the level at which all other currencies in the global system exchange, and when its rules for financial-market activity set the standard for all other nations' rules. A country is partially hegemonic when it defines rules of financial market activity that other nations imitate or follow.

4. ECB (2006) defines such holdings as indicating a 'precautionary motive'; but this term is ambiguous, insofar as it could refer to a nation's need for currency because of its own miscalculations (as when one of its export goods' prices collapsed) or to an external attack (or a sudden withdrawal of external lending).

\section{REFERENCES}

Bertaut, C.C., L.P. DeMarco, S.B. Kamin and R.W. Tryon (2011). ABS inflows to the United States and the global financial crisis. Journal of International Economics 88(2), 219-234.

Bowles, S. (2006). Microeconomics: Behavior, institutions, and evolution. Princeton: Princeton University Press.

Caballero, R.J., E. Farhi and P.-O. Gourinchas (2008). Financial crash, commodity prices, and global imbalances. Brookings Papers on Economic Activity, Fall, 1-55.

Caballero, R.J., E. Farhi and P.-O. Gourinchas (2017). The safe assets shortage conundrum. Journal of Economic Perspectives 31(3), Summer, 29-46.

Caballero, R.J. and A. Krishnamurthy (2009). Global imbalances and financial fragility, NBER Working Paper No. 14688. Cambridge, MA: National Bureau of Economic Research.

Carpintero, O. (2013). When heterodoxy becomes orthodoxy: Ecological economics in The New Palgrave Dictionary of Economics. American Journal of Economics and Sociology 72(5), 1287-1314.

Cohen, Benjamin J. (1998). The Geography of Money. Ithaca: Cornell University Press.

D'Arista, J. (2018). All Fall Down: Debt, deregulation, and financial crisis. Cheltenham, UK and Northampton, MA, USA: Edward Elgar Publishing.

Davidson, P. (1978). Money and the Real World. London: Palgrave Macmillan.

Diaz Alejandro, C.F. (1984). Latin American debt: I don't think we are in Kansas anymore. Brookings Papers on Economic Activity 2, 335-403.

Dominguez, K. (2008). Comment. Brookings Papers on Economic Activity (2), 56-60.

Dow, S. (1987). The treatment of money in regional economics. Journal of Regional Science 27, 13-24.

Dymski, G. (1999). The Bank Merger Wave: Economic causes and social consequences of financial consolidation. New York: M.E. Sharpe.

Dymski, G. (2014). Neoclassical sink and heterodox spiral: Political divides and lines of communication in economics. Review of Keynesian Economics 2(1), 1-19.

Dymski, G. (2019). Post-war international debt crises and their transformation. In J. Michie (ed.), The Handbook of Globalisation (pp. 103-118). Cheltenham, UK and Northampton, MA, USA: Edward Elgar Publishing. 
Dymski, G. (2021). Financial geography, imbalances and crises: Excavating the spatial dimensions of asymmetric power. In J. Knox-Hayes and D. Wójcik (eds), The Routledge Handbook of Financial Geography (pp. 510-531). Cheltenham, UK and Northampton, MA, USA: Edward Elgar Publishing.

Dymski, G. and A. Kaltenbrunner (2021). Space in Post-Keynesian monetary economics: An exploration of the literature. In B. Bonizzi, A. Kaltenbrunner and R.A. Ramos (eds), Emerging Economies and the Global Financial System: Post-Keynesian analysis. London: Routledge.

Eaton, J., M. Gersovitz and J.E. Stiglitz (1986). The pure theory of country risk. European Economic Review 30(3), 481-513.

Eichengreen, B. (2010). Exorbitant Privilege: The rise and fall of the dollar and the future of the international monetary system. Oxford: Oxford University Press.

European Central Bank (ECB) (2006). The accumulation of foreign reserves. Occasional Paper Series, 43. Frankfurt: European Central Bank.

Hamouda, O. and G.C. Harcourt (1988). Post Keynesianism: From criticism to coherence? Bulletin of Economic Research 40(1), 1-33.

Kaltenbrunner, A. and P. Lysandrou (2017). The US dollar's continuing hegemony as an international currency: A double-matrix analysis. Development and Change 48(4), 663-691.

Krugman, P. (1998). What happened to Asia? Working Paper. MIT Department of Economics.

Lavoie, M. (2015). Post-Keynesian Economics: New foundations. Cheltenham, UK and Northampton, MA, USA: Edward Elgar Publishing.

Lee, F. (2009). A History of Heterodox Economics. New York: Routledge.

Lefebvre, H. (1991). The Production of Space. London: Blackwell.

Peet, R. (2013). The Geography of Power: Making global economic policy. London: Zed.

Shackle, G.L.S. (1974). Keynesian Kaleidics. Edinburgh: Edinburgh University Press.

Soja, E.W. (1996). Thirdspace: Journeys to Los Angeles and other real-and-imagined places. Oxford: Blackwell.

Townsend, R. (1983). Financial structure and economic activity. American Economic Review 73(5), 895-911.

Wójcik, D. (2012). The end of investment bank capitalism? An economic geography of financial jobs and power. Economic Geography 88(4), 345-368.

Wójcik, D. (2017). What on earth is financial geography? Global Network on Financial Geography. Retrieved from http://www.fingeo.net/. 